\title{
ANALISIS PENGARUH LAYANAN BELANJA ONLINE TERHADAP PERJALANAN BERBASIS RUMAH DAN TEMPAT AKTIVITAS DENGAN METODE SEM
}

\author{
James Salim $^{1}$ dan Leksmono Suryo Putranto ${ }^{2}$
}

\author{
${ }^{1}$ Program Studi Sarjana Teknik Sipil, Universitas Tarumanagara, Jl. Letjen S. Parman No.1 Jakarta \\ james.325160032@stu.untar.ac.id \\ ${ }^{2}$ Program Studi Sarjana Teknik Sipil, Universitas Tarumanagara, Jl. Letjen S. Parman No.1 Jakarta \\ leksmonop@ft.untar.ac.id
}

Masuk: 06-07-2020, revisi: 04-09-2020, diterima untuk diterbitkan: 22-10-2020

\begin{abstract}
Transportation is an activity which moving a person or an object from one place to another place. Transportation is done not for desire, it is a derived demand for humans to do the activities for fulfiling their daily needs. Shopping is one of the activities that comply their daily needs. Nowdays, online shopping is a trend. Besides easy to do, online shopping can be done any where and any time because of its online system. Along with the growth of online shopping, a lot of people prefer online shopping rather than traditional shopping to shops, markets, shopping centers and other places. This things could change number of people on doing shopping trips. This research aims to find out what factors effects someone's decision to shop online and find out wether online shopping has a direct effect on shopping trips done by people. Data for this reseach collected by quistionnaire. This research will be done with Structural Equation Modeling (SEM) Method. This research shows that experience and trust are strong factors on someone for making decision to shop online and shows that online shopping did not effect directly to people's shopping trips.
\end{abstract}

Keywords: Online Shopping; Shop Decision Factor; Structure Equation Modeling.

\begin{abstract}
ABSTRAK
Transportasi adalah kegiatan perpindahan tempat orang atau suatu benda dari satu tempat ke tempat lainnya. Transportasi dilakukan bukan karena keinginan, melainkan sebuah kebutuhan turunan karena manusia harus melakukan aktivitas untuk memenuhi kebutuhan mereka sehari-hari. Belanja adalah salah satu kegiatan yang dilakukan untuk memenuhi kebutuhan sehari-hari. Belanja online sendiri menjadi sangat trend saat ini. Belanja online selain mudah untuk dilakukan, bisa dilakukan kapan saja, dimana saja karena sistemnya yang bersifat online. Seiring dengan perkembangan belanja online, tidak sedikit orang yang lebih memilih melakukan belanja online dibandingkan melakukan belanja langsung ke toko, pasar, pusat perbelanjaan, dan tempat lainnya. Hal ini bisa jadi mempen garuhi jumlah orang yang melakukan perjalanan belanja. Penelitian ini dilakukan mengetahui faktor apa saja yang berperan dalam keputusan seseorang melakukan belanja online dan mengetahui apakah belanja online berpengaruh secara langsung terhadap perjalanan belanja yang dilakukan masyarakat. Data untuk penelitian didapatkan melalui kuesioner. Penelitian ini akan menggunakan Metode Structural Equation Modeling atau SEM. Dari hasil penelitian didapatkan bahwa pengalaman dan kepercayaan adalah dua faktor yang kuat dalam penentuan keputusan seseorang melakukan belanja online dan belanja online tidak mempengaruhi perjalanan belanja secara langsung.
\end{abstract}

Kata kunci: Belanja Online; Faktor Pengaruh Keputusan Belanja; Structure Equation Modeling.

\section{PENDAHULUAN}

Transportasi adalah kegiatan perpindahan tempat orang atau suatu benda dari satu tempat ke tempat lainnya. Transportasi pastinya terjadi dalam kehidupan manusia sehari-hari. Transportasi dilakukan bukan karena keinginan, melainkan sebuah kebutuhan turunan karena manusia harus melakukan aktivitas untuk memenuhi kebutuhan mereka sehari-hari.

Belanja adalah salah satu kegiatan yang dilakukan untuk memenuhi kebutuhan sehari-hari. Belanja bisa dilakukan untuk membeli bahan makanan, pakaian, barang rumah tangga, kebutuhan sehari-hari, dan kebutuhan lainnya. Namun belanja saat ini bukan hanya untuk memenuhi kebutuhan. Sering kali orang pergi berbelanja untuk bertemu dengan rekan mereka, untuk bersenang-senang, untuk melepas kejenuhan, dan alasan pribadi orang-orang. 
Seiring dengan perkembangan jaman, internet saat ini sudah menjadi sesuatu yang sangat mudah didapatkan masyarakat. Belanja online merupakan salah satu kegiatan yang dapat dilakukan melalui internet. Belanja online sendiri menjadi sangat trend saat ini. Belanja online selain mudah untuk dilakukan, bisa dilakukan kapan saja, dimana saja karena sistemnya yang bersifat online. Selain itu, orang tidak perlu melakukan membuang energi untuk melakukan perjalanan ke pusat perbelanjaan.

Seiring dengan perkembangan belanja online, tidak sedikit orang yang lebih memilih melakukan belanja online dibandingkan melakukan belanja langsung ke toko, pasar, pusat perbelanjaan, dan tempat lainnya. Hal ini bisa jadi mempengaruhi jumlah orang yang melakukan perjalanan belanja

Batasan masalah dalam penelitian ini antara lain:

1. Subjek penelitian merupakan individu yang pernah melakukan belanja online.

2. Subjek penelitian merupakan individu yang melakukan belanja atas keperluannya sendiri bukan merupakan perintah atau suruhan orang lain.

3. Wilayah yang digunakan dalam penelitian ini adalah JABODETABEK (Jakarta, Bogor, Depok, Tangerang, dan Bekasi).

Rumusan masalah yang akan dibahas pada penelitian ini adalah:

1. Apa saja faktor yang berperan dalam keputusan seseorang melakukan belanja online?

2. Seberapa percaya pelaku belanja online dengan vendor atau penjual online?

3. Apakah kegiatan belanja online berpengaruh langsung kepada jumlah perjalanan belanja yang dilakukan masyarakat?

Tujuan dari penelitian ini adalah:

1. Mengetahui faktor yang berperan dalam keputusan seseorang melakukan belanja online.

2. Mengetahui tingkat kepercayaan pelaku belanja online terhadap penjual.

3. Mengetahui apakah kegiatan belanja online berpengaruh langsung kepada jumlah perjalanan belanja yang dilakukan masyarakat.

\section{Transportasi}

Transportasi memiliki peranan penting dalam pembangunan perekonomian, karena berkaitan dengan distribusi barang, jasa, dan tenaga kerja, serta merupakan inti dari pergerakan ekonomi di kota. Kegiatan dari transportasi adalah memindahkan barang (commodity of goods) dan penumpang dari satu tempat (origin atau port of call) ke tempat lain (part of destination), maka dengan demikan pengangkut menghasilkan jasa angkutan atau dengan kata lain produksi jasa bagi masyarakat yang membutuhkan sangat bermanfaat untuk pemindahan atau pengiriman barang-barangnya (Tjakranegara, 1996)

\section{Perjalanan belanja}

Perjalanan, menurut KBBI ialah kepergian (perihal bepergian) dari suatu tempat ke tempat lain. Perjalanan dilakukan smua orang untuk melakukan aktivitas mereka. Perjalanan belanja sendiri merupakan kegiatan bepergian dari suatu tempat menuju tempat lainnya dengan tujuan untuk membeli kebutuhan atau apapun yang mereka butuhkan. Perjalanan belanja sendiri merupakan komponen yang penting dalam lalu lintas karena kegiatan ini berhubungan dengan perjalanan seseorang dan memenuhi kebutuhan hidup.

\section{Belanja online}

Sudah lebih dari 20 tahun, internet digunakan untuk belanja secara online dan menjadi faktor besar yang merubah kebiasaan belanja seseorang (Vaitkevicius \& Mazeikiene, 2019). Belanja online menjadi sangat populer karena bersifat online sehingga praktis untuk dilakukan karena dapat dilakukan kapan saja dan di mana saja. Dengan belanja online, individu tidak perlu berpergian, yang berartu akan menghemat waktu dan biaya transportasi, dan juga tidak perlu repot membawa belanjaan karena barang diantar ke rumah atau ke tempat yang diinginkan (Grewal, Dhruv, Michael, \& Donald, 2004).

Walaupun belanja online sudah sangat populer dan berkembang, Solomon (1986) sebagaimana dikutip oleh (Hendra, Wirza, \& Irawan, 2015) berpendapat bahwa keputusan seseorang untuk berbelanja secara online, secara tidak langsung akan berpengaruh terhadap perilaku perjalanan seseorang, seperti substitusi (belanja online menggantikan belanja secara konvensional), modifikasi (mengubah karakteristik perjalanan belanja), komplementer (melengkapi perjalanan belanja), atau netral (tidak berpengaruh terhadap perjalanan belanja). Gould dan Golob (1998) sebagaimana dikutip oleh (Hendra, Wirza, \& Irawan, 2015) juga berpendapat bahwa Belanja online hanya bersifat melengkapi dan bukan menggantikan metode belanja secara tradisional (ke toko) karena masyarakat pada umumnya masih ingin memiliki 
pengalaman berbelanja secara tradisional dan mungkin akan melakukan belanja online sebagai peningkatan pengalaman berbelanja.

\section{METODE PENELITIAN}

Alur atau tahapan dari penelitian ini tertera dalam bentuk diagram pada gambar 1.

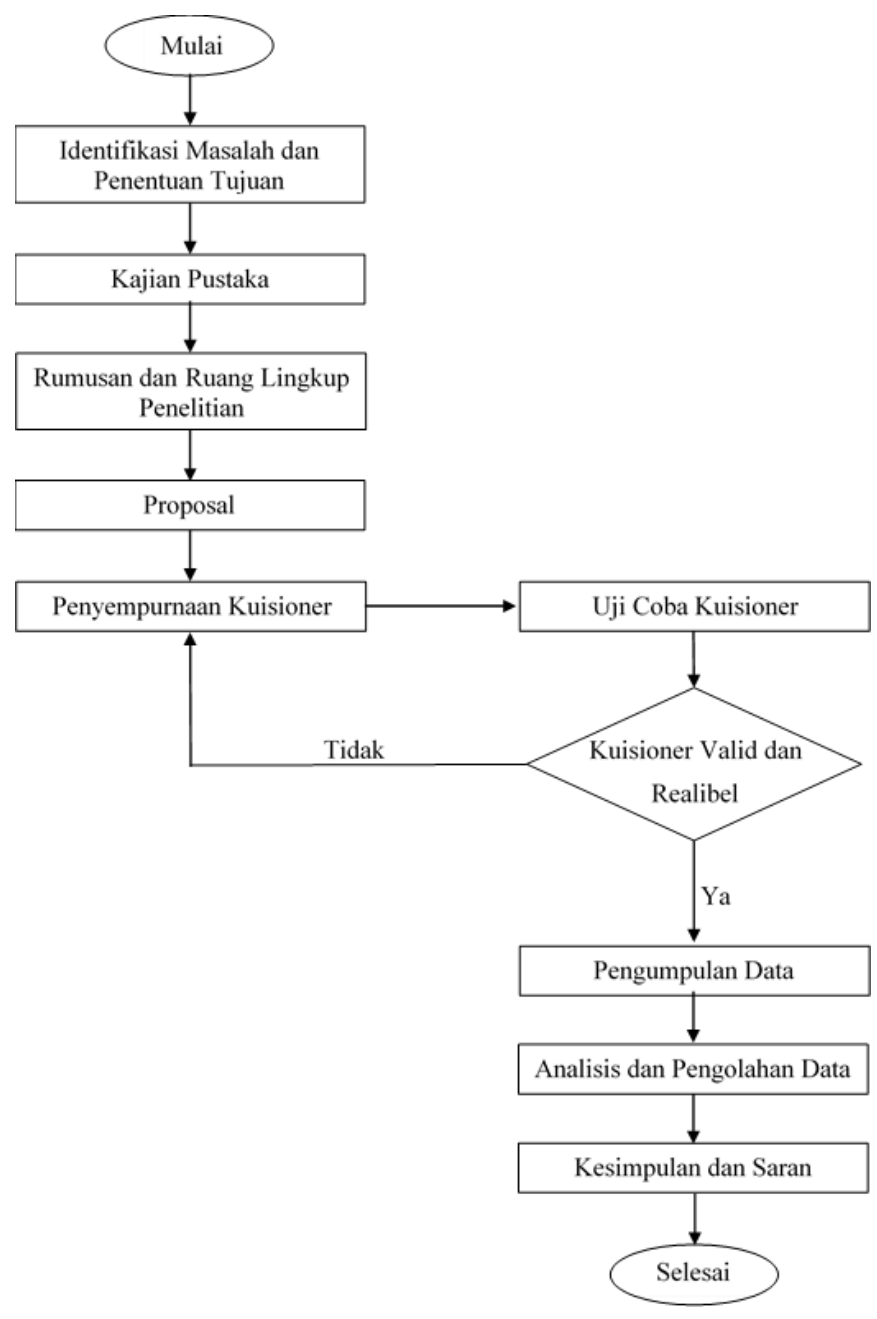

Gambar 1. Diagram alur penelitian

Pada penelitian ini pengumpulan data dilakukan menggunakan metode kuesioner. Kuesioner merupakan sejumlah pertanyaan atau pernyataan tertulis tentang data faktual atau opini yang berkaitan dengan diri responden, yang dianggap fakta atau kebenaran yang diketahui dan perlu dijawab oleh responden (Sutoyo, 2009)

Dalam penelitian ini kuesioner disusun dengan menggunakan skala likert dan pertanyaan terbuka. Pada penelitian ini skala likert dibuat dalam skala frekuensi dan skala kesetujuan. Skala likert yang digunakan adalah skala dengan nilai genap (4). Penggunaan skala berjumlah genap dikarenakan bila terdapat skor netral (titik tengah), responden cenderung memilih titik di tengah. Kuesioner dibuka dengan pertanyaan mengenai data umum responden. Setelah mengisi data umum, responden akan mengisi pertanyaan penyaring yaitu apakah responden pernah melakukan belanja online atau tidak. Apabila responden tidak sesuai dengan kriteria, maka akan dimintai alasan dan data akan tetap disimpan untuk keperluan analisis. Setelah itu kuesioner dilanjutkan dengan pertanyaan-pertanyaan mengenai kebiasan belanja responden baik secara online maupun secara langsung ke toko fisik.

Penelitian ini menargetkan responden sejumlah 100 individu yang bertempat tinggal di wilayah Jabodetabek. Berdasarkan riset yang dilakukan oleh Katadata Insight Center (KIC) berjudul "Indonesia E-commerce Mapping 2018" yang dilakukan terhadap 20 ribu pengguna e-commerce di 34 provinsi di Indonesia, sebesar 52,97\% dari total responden pengguna layanan $e$-commece merupakan pria. Berdasarkan riset tersebut, maka target responden pada penelitian ini adalah 53\% pria (53 responden) dan $47 \%$ wanita (47 responden). Indikator yang digunakan pada penelitian ini akan disajikan pada tabel 1 . 
Tabel 1. Data penelitian

\begin{tabular}{|c|c|c|}
\hline NO. & BAGIAN & INDIKATOR \\
\hline \multirow[t]{8}{*}{1} & Data Umum & Jenis Kelamin \\
\hline & & Usia \\
\hline & & Pendidikan Terakhir \\
\hline & & Pekerjaan \\
\hline & & Domisili \\
\hline & & Pengeluaran Pribadi per Bulan \\
\hline & & Kepemilikan Kendaraan \\
\hline & & Kualitas Internet yang Didapat \\
\hline \multirow[t]{7}{*}{2} & Karakteristik Belanja Online & Frekuensi Belanja Online \\
\hline & & Produk Belanja Online \\
\hline & & Harga Produk \\
\hline & & Situs Belanja Online \\
\hline & & Alasan Belanja Online \\
\hline & & Kepercayaan Kepada Penjual \\
\hline & & Metode Pembayaran \\
\hline \multirow[t]{3}{*}{3} & Karakteristik Belanja Langsung & Frekuensi Belanja Langsung \\
\hline & & Tujuan Belanja Langsung \\
\hline & & Basis Perjalanan Belanja \\
\hline
\end{tabular}

Pengumpulan data kuesioner dilakukan secara online dikarenakan saat penelitian dilaksanakan sedang terjadi pandemi COVID-19 dan diberlakukannya Pembatasan Sosial Berskala Besar atau PSBB sehingga tidak memungkinkan untuk melakukan penyebaran kuesioner secara langsung.

Data hasil yang didapatkan dari kuesioner disusun, dikelompokkan dan dianalisis dengan menggunakan suatu cara atau rumusan. Data-data yang didapat akan dianalisis menggunakan program IBM Statistical Package for Social Sciences (SPSS) Statistics versi 26. Hasil penelitian dapat dikatakan terpercaya apabila data yang didapat merupakan data yang valid dan realibel. Maka atas dasar tersebut dilakukan pengujian untuk menentukan validitas dan realibitas dari data yang terkumpul.

Prihandini \& Sunaryo (2011) menyatakan Structural Equation Modeling disingkat SEM pada dasarnya merupakan metode analisis multivariat yang dapat digunakan untuk menggambarkan keterkaitan hubungan linier secara simultan antara variabel pengamatan dan variabel yang tidak dapat diukur secara langsung. Untuk penyelesaian SEM, maka digunakan juga program IBM SPSS AMOS (Analysis Moment of Structural) versi 26. AMOS adalah salah satu program khusus yang digunakan untuk menyelesaikan SEM.

\section{HASIL DAN PEMBAHASAN}

\section{Analisis data deskriptif}

Pada tahap perencanaan penelitian, jumlah responden yang direncanakan adalah 100 orang. Data umum mencakup jenis kelamin responden, usia responden, domisili responden, pendidikan terakhir responden, pekerjaan responden, sifat pekerjaan responden, pengeluaran pribadi rata-rata responden dalam sebulan, jumlah kendaraan yang dimiliki responden pada tempat tinggal mereka saat ini, dan kualitas internet yang didapatkan responden. Pada tabel 2 disajikan hasil rekapitulasi data umum yang didapatkan dari kuesioner. 
Tabel 2. Data umum responden

\begin{tabular}{|c|c|c|}
\hline & Data Umum & Jumlah \\
\hline \multirow{6}{*}{ Usia } & $<19$ tahun & 2 \\
\hline & 19 tahun & 26 \\
\hline & 20 tahun & 17 \\
\hline & 21 tahun & 26 \\
\hline & 22 tahun & 20 \\
\hline & $>22$ tahun & 9 \\
\hline \multirow{4}{*}{ Domisili } & Jakarta & 68 \\
\hline & Tangerang & 25 \\
\hline & Depok & 3 \\
\hline & Bekasi & 4 \\
\hline \multirow{3}{*}{$\begin{array}{l}\text { Pendidikan } \\
\text { Terakhir }\end{array}$} & $\leq$ SMA Sederajat & 81 \\
\hline & Diploma & 4 \\
\hline & Sarjana (S1) & 15 \\
\hline \multirow{4}{*}{ Pekerjaan } & Pelajar / Mahasiswa & 84 \\
\hline & Pegawai & 8 \\
\hline & Guru & 2 \\
\hline & Lainnya & 6 \\
\hline \multirow{5}{*}{$\begin{array}{l}\text { Pengeluaran } \\
\text { Pribadi Rata-Rata } \\
\text { Selama Sebulan }\end{array}$} & $<\mathrm{Rp} 1.000 .000$ & 38 \\
\hline & $\mathrm{Rp} 1.000 .000 \mathrm{~s} / \mathrm{d} \mathrm{Rp} 2.000 .000$ & 31 \\
\hline & $\mathrm{Rp} 2.000 .000 \mathrm{~s} / \mathrm{d} \mathrm{Rp} 3.000 .000$ & 16 \\
\hline & $\mathrm{Rp} 3.000 .000 \mathrm{~s} / \mathrm{d} \operatorname{Rp} 4.000 .000$ & 5 \\
\hline & $>\mathrm{Rp} 4.000 .000$ & 10 \\
\hline \multirow{6}{*}{$\begin{array}{l}\text { Jumlah } \\
\text { Kepemilikan } \\
\text { Mobil }\end{array}$} & 0 & 26 \\
\hline & 1 & 42 \\
\hline & 2 & 23 \\
\hline & 3 & 4 \\
\hline & 4 & 3 \\
\hline & 5 & 2 \\
\hline \multirow{6}{*}{$\begin{array}{l}\text { Jumlah } \\
\text { Kepemilikan } \\
\text { Motor }\end{array}$} & 0 & 24 \\
\hline & 1 & 35 \\
\hline & 2 & 24 \\
\hline & 3 & 10 \\
\hline & 4 & 5 \\
\hline & 5 & 2 \\
\hline \multirow{2}{*}{$\begin{array}{l}\text { Kualitas Internet } \\
\text { yang Didapat }\end{array}$} & Baik & 83 \\
\hline & Tidak & 17 \\
\hline
\end{tabular}


Berdasarkan tabel 2, dapat dilihat bahwa sebagian besar responden merupakan orang yang berada dalam kategori usia remaja dengan rata-rata usia responden 20.98 tahun. Hal ini sesuai dengan mayoritas pekerjaan responden yaitu pelajar atau mahasiswa. Selain pengeluaran rata-rata perbulan responden rata-rata berada dalam rentang $\mathrm{Rp} 1.000 .000$,sampai Rp 2.000.000,-. Selain itu sebagian besar responden memiliki kendaraan di tempat yang sedang mereka tinggali saat ini. Kemudian dapat dilihat dari 100 orang responden, 83 orang mengaku mereka mendapatkan kualitas internet yang baik.

Pada tabel 3, akan ditampilkan data mengenai frekuensi responden melakukan belanja online.

Tabel 3. Frekuensi responden melakukan belanja online

\begin{tabular}{cc}
\hline Frekuensi & Jumlah Responden \\
\hline 1 (Sangat Jarang) & 25 \\
2 (Sebulan Sekali) & 39 \\
3 (Seminggu Sekali) & 23 \\
4 (2-4kali Seminggu) & 12 \\
5 (Setiap Hari) & 1 \\
\hline Jumlah & 100 \\
\hline Rataan & 2,25 \\
\hline
\end{tabular}

Pada tabel 4 akan ditampilkan data mengenai frekuensi prouduk yang biasa dibeli oleh responden. Pertanyaan pada tabel 4. menggunakan skala likert 1 sampai 4, dengan 1 (hampir tidak pernah), 2 (jarang), 3 (sering) dan 4 (sangat sering).

Tabel 4. Jumlah data (N), nilai minimal, nilai maksimum dan mean frekuensi produk yang dibeli

\begin{tabular}{lcccc}
\hline \multicolumn{1}{c}{ Indikator } & N & Min. & Max. & Mean \\
\hline Produk Fashion & 100 & 1 & 4 & 2,46 \\
Produk Peralatan Rumah Tangga & 100 & 1 & 4 & 1,78 \\
Produk Gadget & 100 & 1 & 4 & 2,22 \\
Produk Alat Tulis & 100 & 1 & 4 & 1,88 \\
Produk Otomotif & 100 & 1 & 4 & 1,41 \\
Produk Hobi & 100 & 1 & 4 & 2,83 \\
Produk Makanan dan Bahannya & 100 & 1 & 4 & 2,46 \\
Produk Obat-Obatan & 100 & 1 & 4 & 2,46 \\
Produk Furniture & 100 & 1 & 4 & 1,78 \\
Tiket & 100 & 1 & 4 & 2,22 \\
Produk Lainnya & 100 & 1 & 4 & 1,88 \\
\hline
\end{tabular}

Pada tabel 5 akan ditampilkan data mengenai rata-rata harga produk yang biasa dibeli oleh responden. Pertanyaan pada tabel 5 menggunakan skala 1 sampai 5 dengan 1 (tidak pernah), 2 (< Rp 1.000.000), 3 (Rp 1.000.000 s/d Rp 2.500.000), 4 (Rp 2.500.000 s/d Rp 5.000.000), dan 5 (> Rp 5.000.000).

Tabel 5. Jumlah data (N), nilai minimal, nilai maksimum dan mean frekuensi harga produk yang dibeli

\begin{tabular}{lcccc}
\hline \multicolumn{1}{c}{ Indikator } & N & Min. & Max. & Mean \\
\hline Produk Fashion & 100 & 1 & 5 & 2,02 \\
Produk Peralatan Rumah Tangga & 100 & 1 & 4 & 1,72 \\
\hline
\end{tabular}


Tabel 5. Jumlah data $(\mathrm{N})$, nilai minimal, nilai maksimum dan mean frekuensi harga produk yang dibeli (Lanjutan)

\begin{tabular}{lcccr}
\hline \multicolumn{1}{c}{ Indikator } & $\mathrm{N}$ & Min. & Max. & Mean \\
\hline Produk Gadget & 100 & 1 & 5 & 2,30 \\
Produk Alat Tulis & 100 & 1 & 4 & 1,67 \\
Produk Otomotif & 100 & 1 & 5 & 1,55 \\
Produk Hobi & 100 & 1 & 5 & 2,20 \\
Produk Makanan dan Bahannya & 100 & 1 & 4 & 1,92 \\
Produk Obat-Obatan & 100 & 1 & 4 & 1,58 \\
Produk Furniture & 100 & 1 & 4 & 1,58 \\
Tiket & 100 & 1 & 5 & 2,20 \\
Produk Lainnya & 100 & 1 & 4 & 1,53 \\
\hline
\end{tabular}

Pada tabel 6 akan ditampilkan data mengenai situs online yang biasa digunakan oleh responden saat melakukan belanja online. Pertanyaan pada tabel 6 menggunakan skala likert 1 sampai 4, dengan 1 (hampir tidak pernah), 2 (jarang), 3 (sering), dan 4 (sangat sering).

Tabel 6. Jumlah data (N), nilai minimal, nilai maksimum dan mean situs online yang biasa digunakan

\begin{tabular}{lcccc}
\hline \multicolumn{1}{c}{ Indikator } & $\mathrm{N}$ & Min. & Max. & Mean \\
\hline Shopee & 100 & 1 & 4 & 3,05 \\
Tokopedia & 100 & 1 & 4 & 2,99 \\
JD.ID & 100 & 1 & 4 & 1,26 \\
Blibli.com & 100 & 1 & 4 & 1,27 \\
Lazada & 100 & 1 & 4 & 1,52 \\
Bukalapak & 100 & 1 & 4 & 1,56 \\
Zalora & 100 & 1 & 4 & 1,69 \\
Elevenia & 100 & 1 & 3 & 1,08 \\
MatahariMall & 100 & 1 & 3 & 1,08 \\
Via Sosial Media & 100 & 1 & 4 & 2,12 \\
Situs Lainnya & 100 & 1 & 4 & 1,19 \\
\hline
\end{tabular}

Hasil rekapitulasi data dan pengujian validitas akan disajikan pada tabel 7. Pertanyaan mengenai alasan melakukan belanja online, skala yang digunakan adalah skala likert 1 sampai 4, dengan 1 (sangat tidak setuju), 2 (tidak setuju), 3 (setuju), dan 4 (sangat setuju).

Tabel 7. Jumlah data $(\mathrm{N})$, nilai minimal, nilai maksimum, mean, dan hasil uji validitas variabel alasan belanja online

\begin{tabular}{lccccccc}
\hline \multicolumn{1}{c}{ Indikator } & $\mathrm{N}$ & Min. & Max. & Mean & $\mathrm{R}$ & Sig. & Valid? \\
\hline Praktis & 100 & 2 & 4 & 3,48 & 0,552 & $<0,001$ & Ya \\
Promo & 100 & 2 & 4 & 3,27 & 0,596 & $<0,001$ & Ya \\
Banyak Pilihan Pembayaran & 100 & 1 & 4 & 2,39 & 0,544 & $<0,001$ & Ya \\
\hline
\end{tabular}


Tabel 7. Jumlah data $(\mathrm{N})$, nilai minimal, nilai maksimum, mean, dan hasil uji validitas variabel alasan belanja online (Lanjutan)

\begin{tabular}{lccccccc}
\hline \multicolumn{1}{c}{ Indikator } & $\mathrm{N}$ & Min. & Max. & Mean & $\mathrm{R}$ & Sig. & Valid? \\
\hline Lebih Lengkap & 100 & 2 & 4 & 3,27 & 0,589 & $<0,001$ & Ya \\
Lebih Mudah Membandingkan & 100 & 2 & 4 & 2,91 & 0,690 & $<0,001$ & Ya \\
Lain-lain & 100 & 1 & 3 & 1,33 & 0,414 & $<0,001$ & Ya \\
\hline
\end{tabular}

Setelah melakukan uji validitas untuk variabel alasan belanja online, maka dilakukan uji reabilitas dan didapatkan nilai Cronbach's Alpha sebesar 0,603. Dengan nilai Cronbach's Alpha tersebut maka dapat dibilang variabel yang diuji reliabel. Kemudian pada tabel 8 akan disajikan hasil rekapitulasi data dan pengujian validitas. Pertanyaan mengenai kepercayaan terhadap toko online, skala yang digunakan adalah skala likert 1 sampai 4, dengan 1 (sangat tidak setuju), 2 (tidak setuju), 3 (setuju), dan 4 (sangat setuju).

Tabel 8. Jumlah data (N), nilai minimal, nilai maksimum, mean, dan hasil uji validitas variabel kepercayaan terhadap toko online

\begin{tabular}{lccccccc}
\hline \multicolumn{1}{c}{ Indikator } & $\mathrm{N}$ & Min. & Max. & Mean & $\mathrm{R}$ & Sig. & Valid? \\
\hline Keamanan & 100 & 1 & 4 & 3,50 & 0,638 & $<0,001$ & Ya \\
Kualitas & 100 & 2 & 4 & 3,25 & 0,724 & $<0,001$ & Ya \\
Kecepatan Transaksi & 100 & 2 & 4 & 3,13 & 0,763 & $<0,001$ & Ya \\
Kecepatan Pengiriman & 100 & 1 & 4 & 3,24 & 0,761 & $<0,001$ & Ya \\
Kecocokan Produk & 100 & 2 & 4 & 3,27 & 0,813 & $<0,001$ & Ya \\
\hline
\end{tabular}

Setelah melakukan uji validitas untuk variabel kepercayaan terhadap toko online, maka dilakukan uji reabilitas dan didapatkan nilai Cronbach's Alpha sebesar 0,795. Dengan demikian data tersebut dinyatakan valid dan realibel. Pada tabel 9 dan tabel 10 akan disajikan hasil rekapitulasi data mengenai pengalaman buruk saat belanja online yang didapatkan oleh responden.

Tabel 9. Jumlah Responden Yang Pernah Mendapat Pengalaman Buruk Saat Belanja Online

\begin{tabular}{cc}
\hline Pengalaman Buruk & Jumlah Responden \\
\hline Pernah & 72 \\
Tidak Pernah & 28 \\
\hline Jumlah & 100 \\
\hline
\end{tabular}

Tabel 10. Jumlah Data (N), Nilai Minimal, Nilai Maksimum, Mean, dan hasil uji validitas variabel pengalaman buruk yang didapat saat melakukan belanja online

\begin{tabular}{lccccccc}
\hline \multicolumn{1}{c}{ Indikator } & $\mathrm{N}$ & Min. & Max. & Mean & $\mathrm{R}$ & Sig. & Valid? \\
\hline Barang Rusak & 100 & 2 & 4 & 3,39 & 0,596 & $<0,001$ & Ya \\
Respon Penjual & 100 & 1 & 4 & 3,09 & 0,753 & $<0,001$ & Ya \\
Pengiriman Lama & 100 & 1 & 4 & 2,57 & 0,770 & $<0,001$ & Ya \\
Transaksi Palsu & 100 & 2 & 4 & 3,84 & 0,146 & 0,074 & Tidak \\
Barang Tidak Sesuai Pesanan & 100 & 1 & 4 & 3,06 & 0,724 & $<0,001$ & Ya \\
Barang Tidak Sesuai Iklan & 100 & 1 & 4 & 3,24 & 0,712 & $<0,001$ & Ya \\
Pengalaman Buruk Lainnya & 100 & 2 & 4 & 3,86 & 0,180 & 0,037 & Ya \\
\hline
\end{tabular}


Berdasarkan tabel 10, terdapat 1 variabel (Transaksi Palsu) tidak valid. Karena indikator dinyatakan tidak valid, maka indikator tersebut dihapus dan dilakukan uji reabilitas dan didapatkan nilai Cronbach's Alpha sebesar 0,703. Dengan demikian data tersebut dinyatakan valid dan realibel. Untuk tabel 11, akan disajikan data mengenai metode pembayaran yang biasa digunakan oleh pengguna saat melakukan belanja online. Pertanyaan mengenai metode pembayaran yang biasa digunakan menggunakan skala likert 1 sampai 4, dengan 1 (hampir tidak pernah), 2 (jarang), 3 (sering), dan 4 (sangat sering).

Tabel 11. Jumlah data (N), nilai minimal, nilai maksimum dan mean situs metode pembayaran yang digunakan

\begin{tabular}{lcccc}
\hline \multicolumn{1}{c}{ Indikator } & $\mathrm{N}$ & Min. & Max. & Mean \\
\hline Kartu Kredit & 100 & 1 & 4 & 1,56 \\
Mbanking & 100 & 1 & 4 & 3,59 \\
$\begin{array}{l}\text { Cash On Delivery } \\
\text { (Kurir datang ke tempat pembeli) }\end{array}$ & 100 & 1 & 4 & 1,76 \\
$\begin{array}{l}\text { Cash On Delivery } \\
\text { (Pembeli dan penjual bertemu) }\end{array}$ & 100 & 1 & 4 & 1,35 \\
$\begin{array}{l}\text { Transfer Bank } \\
\text { Ewallet }\end{array}$ & 100 & 1 & 4 & 2,69 \\
Supermarket & 100 & 1 & 4 & 3,01 \\
\hline
\end{tabular}

Berdasarkan tabel 11, dapat dilihat bahwa metode pembayaran yang sering digunakan adalah metode pembayaran yang bisa dilakukan kapanpun dan di mana pun. Metode pembayaran yang paling jarang digunakan adalah metode Cash On Delivery dimana pembeli harus melakukan pertemuan dengan penjual di tempat yang sudah ditentukan

Pada tabel 12 sampai dengan tabel 16 akan disajikan hasil rekapitulasi data mengenai karakteristik belanja langsung yang dilakukan responden.

Tabel 12. Jumlah responden yang masih melakukan belanja langsung

\begin{tabular}{cc}
\hline Belanja Langsung & Jumlah Responden \\
\hline Masih & 96 \\
Tidak & 4 \\
\hline Jumlah & 100
\end{tabular}

Tabel 13. Jumlah data $(\mathrm{N})$, nilai minimal, nilai maksimum, mean, dan hasil uji validitas variabel destinasi belanja langsung

\begin{tabular}{lccccccc}
\hline \multicolumn{1}{c}{ Indikator } & N & Min. & Max. & Mean & R & Sig. & Valid? \\
\hline Pasar Tradisional & 96 & 1 & 4 & 2,39 & 0,610 & $<0,001$ & Ya \\
Pusat Perbelanjaan (Plaza, Mall, dll.) & 96 & 1 & 4 & 3,13 & 0,667 & $<0,001$ & Ya \\
Toko Modern (Supermarket, dll.) & 96 & 1 & 4 & 3,35 & 0,632 & $<0,001$ & Ya \\
\hline
\end{tabular}

Setelah melakukan uji validitas untuk variabel belanja langsung, maka dilakukan uji reabilitas dan didapatkan nilai Cronbach's Alpha sebesar 0,296. Hal ini disebabkan pada indikator pasar tradisional, jawaban dari responden memilki respon yang tidak baik. Apabila Indikator tersebut dihapus, maka didapatkan Cronbach's Alpha sebesar 0,736. 
Tabel 14. Tujuan belanja langsung yang lebih disukai

\begin{tabular}{lc}
\hline \multicolumn{1}{c}{ Indikator } & Jumlah Responden \\
\hline Pasar Tradisional & 11 \\
Pusat Perbelanjaan (Plaza, Mall, dll.) & 54 \\
Toko Modern (Supermarket, dll.) & 31 \\
\hline Jumlah & 96 \\
\hline
\end{tabular}

Tabel 15. Jumlah data $(\mathrm{N})$, frekuensi, dan mean jenis perjalanan yang biasa dilakukan

\begin{tabular}{llrrrrrr}
\hline No. & Indikator & $\mathrm{N}-$ & \multicolumn{2}{c}{ Skala } & \multicolumn{2}{c}{ Mean } \\
& & & 1 & 2 & 3 & 4 & \\
\hline 1 & Rumah Ke Tempat Belanja & 96 & 2 & 16 & 53 & 29 & 3,09 \\
2 & Tempat Aktivitas Ke Tempat Belanja & 96 & 7 & 29 & 43 & 21 & 2,78 \\
\hline
\end{tabular}

Tabel 16. Pendapat responden apakah belanja online bisa mengurangi belanja langsung

\begin{tabular}{cc}
\hline Indikator & Jumlah Responden \\
\hline Ya & 72 \\
Tidak & 28 \\
\hline Jumlah & 100 \\
\hline
\end{tabular}

Berdasarkan tabel 12, dapat dilihat bahwa $96 \%$ responden yang melakukan belanja online menyatakan bahwa mereka masih melakukan belanja langsung. Hal tersebut sesuai dengan pendapat Gould dan Golob (1998), bahwa belanja online hanya bersifat melengkapi dan bukan menggantikan metode belanja secara tradisional (ke toko) karena masyarakat pada umumnya masih ingin memiliki pengalaman berbelanja secara tradisional dan mungkin akan melakukan belanja online sebagai peningkatan pengalaman berbelanja. Selain itu menurut Graham dan Marvin (1996), online shopping melengkapi bukan menggantikan metode belanja secara tradisional (ke toko).

Pada tabel 14, tujuan belanja langsung yang paling disukai oleh responden yang melakukan belanja langsung adalah Pusat Perbelanjaan (Plaza, Mall, dan lain-lain) dengan persentase 56,25\%. Hal ini sesuai dengan pendapat Tacken (1999), dimana ia mengatakan bahwa perjalanan belanja dibagi menjadi dua kategori, belanja fungsional (functional shopping), dimana pembeli mencari produk atau jasa untuk memenuhi kebutuhan pribadi atau keluarga, dan belanja untuk hiburan (recreational shopping), dimana pembeli melakuan kegiatan belanja sebagai interaksi dengan orang lain secara sosial atau untuk hiburan pribadi.

Berdasarkan tabel 15, hasil kuis kuisioner menunjukan bahwa respoden lebih sering melakukan perjalanan belanja dari rumah dibandingkan dari tempat aktivitas $(3,09)$. Hal ini juga dapat menunjukkan bahwa pelaku belanja langsung melakukan perjalanan belanja secara sengaja dari rumah.

\section{Structural Equation Modeling (SEM)}

Untuk metode Structural Equation Modeling (SEM), akan dibuat sebuah model persamaan. Namun model tersebut akan dianalisis dengan data keseluruhan, dan dikelompokan. Kelompok data yangg digunakan dikelompokkan berdasarkan jenis kelamin responden (laki-laki dan perempuan), jenis pekerjaan responden (fulltime atau senggang), pengeluaran rata-rata responden selama sebulan, dan berdasarkan kualitas internet yang didapat oleh responden (baik atau buruk). Namun dikarenakan program yang digunakan untuk mengerjakan metode ini (AMOS) tidak bisa digunakan apabila data yang terdapat dibawah 50, maka dari beberapa kelompok data yang digunakan hanya dilihat yang dominan. Angka yang tertera pada panah dalam model SEM disebut dengan koefisien jalur. Untuk melihat besar pengaruh variabel tersebut, angka koefisien jalur harus dikuadratkan.

Berikut adalah beberapa model SEM yang sudah dibuat. Pada gambar 2 akan ditampikan hasil model SEM secara keseluruhan. Kemudian pada tabel 17 hasil uji kecocokan model SEM. 


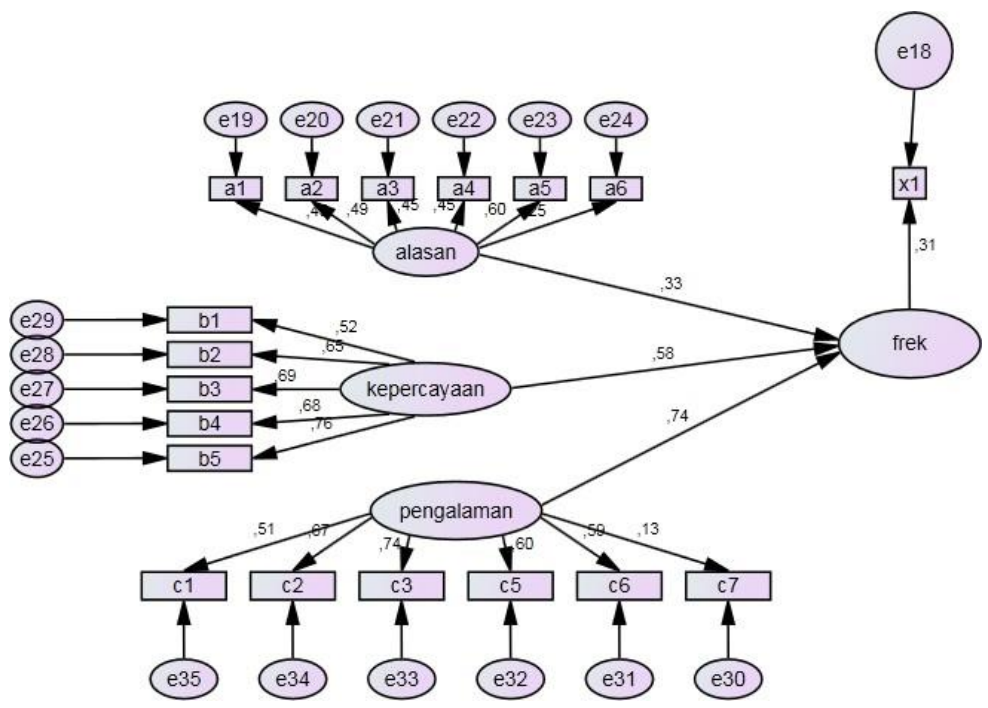

Gambar 2. Hasil model SEM secara keseluruhan

Berdasarkan pada gambar 2 setelah angka koefisien jalur dikuadratkan, maka didapatkan kekuatan hubungan variabel alasan terhadap frekuensi belanja seseorang seberar 10,89\%. Untuk variabel kepercayaan mempengaruhi frekuensi belanja online seseorang sebesar 33,64\% dan untuk variabel pengalaman berpengaruh sebesar 54,76\%.

Tabel 17. Hasil uji kecocokan model SEM

\begin{tabular}{lccc}
\hline \multicolumn{1}{c}{ Goodness Of Fit } & Cut-Off Value & Hasil Uji & Keterangan \\
\hline X2 Chi Square & Diharapkan Kecil & 177,073 & Kurang Baik \\
Probabilitas & $\geq 0,05$ & 0,01 & Kurang Baik \\
CMIN/DF & $\leq 2,00$ & 1,331 & Baik (good fit) \\
RMSEA & $\leq 0,08$ & 0,058 & Baik (good fit) \\
GFI & $\geq 0,90$ & 0,849 & Marginal Fit \\
AGFI & $\geq 0,90$ & 0,806 & Marginal Fit \\
TLI & $\geq 0,95$ & 0,841 & Marginal Fit \\
CFI & $\geq 0,95$ & 0,862 & Marginal Fit \\
\hline
\end{tabular}

Berdasarkan tabel 17, bisa dilihat bahwa terdapat 6 indikator yang memiliki hasil kurang baik. GFI adalah indikator yang melihat fitness suatu model. Pada model yang sudah dibuat, GFI bernilai 0,849 dimana hasil tersebut hampir mendekati nilai standar minimum. Walaupun terdapat indikator yang memiliki hasil yang kurang baik, terdapat pula hasil yang menunjukan hasil baik. Nilai RMSEA merupakan indeks kelayakan model yang mengukur penyimpangan nilai parameter suatu model dengan matriks kovarian populasi. Nilai RMSEA sebesar 0,058 telah memenuhi kriteria yang disarankan yaitu di bawah 0,08, sehingga kelayakan model berdasarkan RMSEA adalah baik. Selain itu nilai CMIN/DF juga menunjukan hasil yang baik. Hal ini menunjukan bahwa adanya acceptable fit antara model dan data.

Untuk mendapatkan hasil fitness yang lebih baik, bisa dilakukan, modifikasi model, seperti menghilangkan atau menambah variabel dan merubah hubungan antar variabel. Hasil yang ditampilkan merupakan hasil terbaik setelah mencoba merubah beberapa hubumgan dan penghapusan variabel yang tidak valid.

Pada gambar 3 sampai gambar 5 akan ditampilkan hasil dari model SEM berdasarkan jenis kelamin (laki-laki), sifat pekerjaan (senggang), dan pengeluaran perbulan ( $\leq$ Rp 2.000.000,-). 


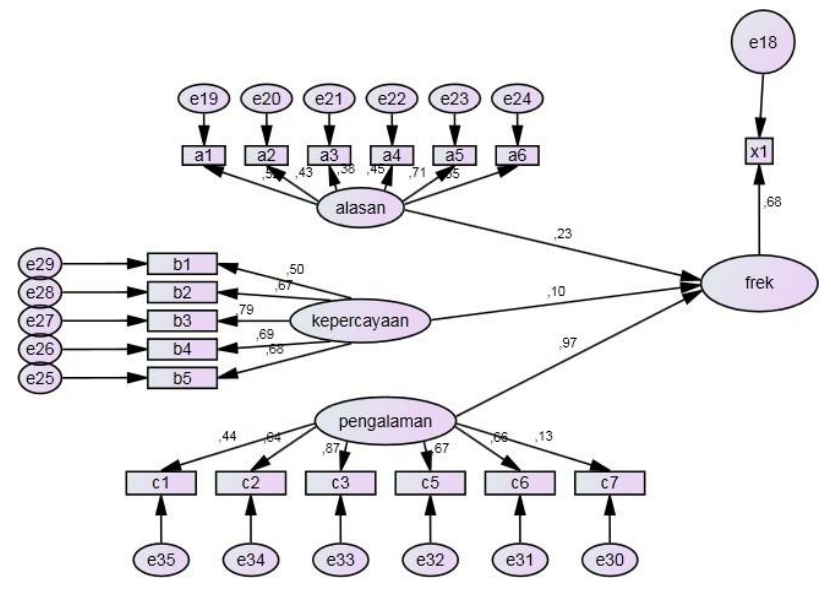

Gambar 3. Hasil model SEM berdasarkan jenis kelamin (laki-laki)

Berdasarkan pada gambar 3 setelah angka koefisien jalur dikuadratkan, maka didapatkan kekuatan hubungan variabel alasan terhadap frekuensi belanja seseorang sebesar 5,23\%. Untuk variabel kepercayaan mempengaruhi frekuensi belanja online seseorang sebesar 1,00\% dan untuk variabel pengalaman berpengaruh sebesar 94,09\%.

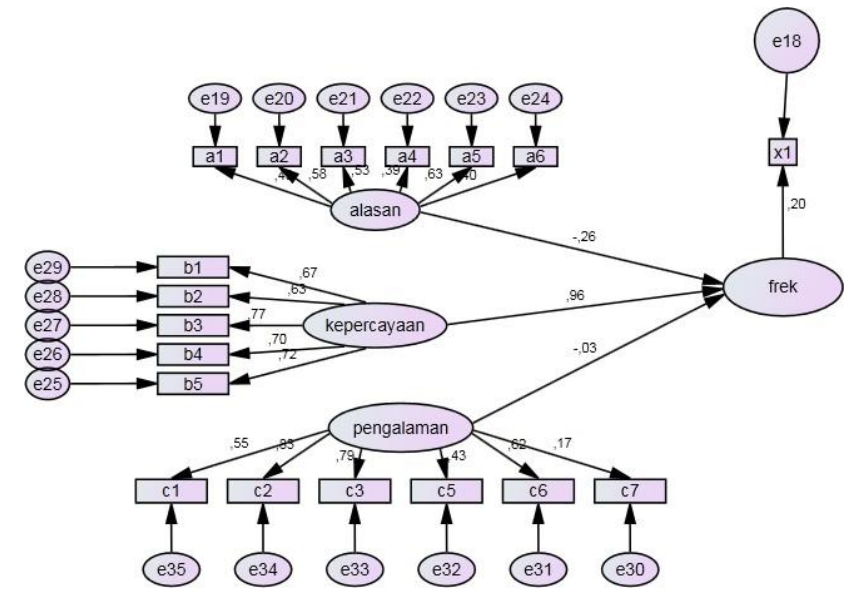

Gambar 4. Hasil model SEM berdasarkan sifat pekerjaan (senggang)

Berdasarkan gambar 4 setelah angka koefisien jalur dikuadratkan, maka didapatkan kekuatan hubungan variabel alasan terhadap frekuensi belanja seseorang sebesar 6,76\%. Untuk variabel kepercayaa nempengaruhi frekuensi belanja online seseorang sebesar $92,16 \%$ dan untuk variabel pengalaman berpengaruh sebesar 0,09\%.

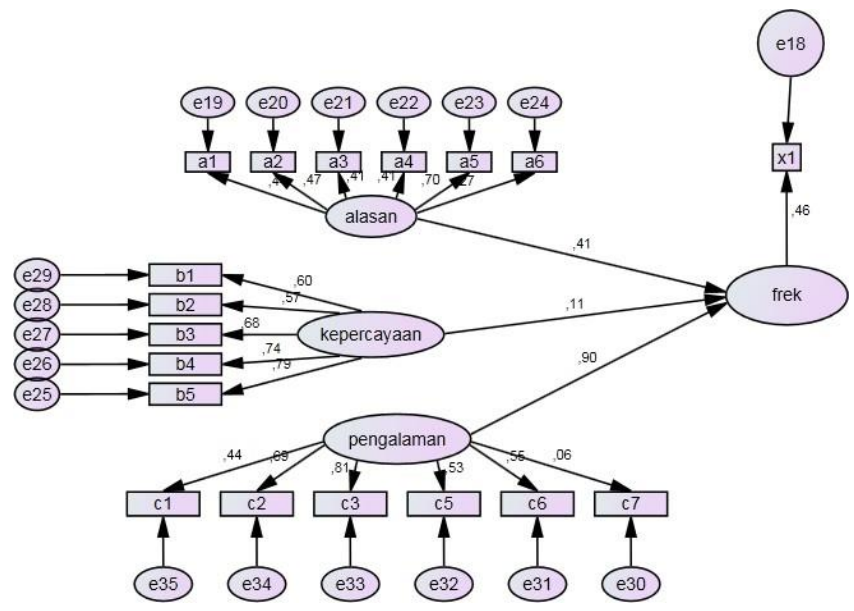

Gambar 5. Hasil model SEM berdasarkan pengeluaran perbulan $(\leq \mathrm{Rp} 2.000 .000,-)$ 
Berdasarkan pada gambar 5 setelah angka koefisien jalur dikuadratkan, maka didapatkan kekuatan hubungan variabel alasan terhadap frekuensi belanja seseorang sebesar 16,81\%. Untuk variabel kepercayaan mempengaruhi frekuensi belanja online seseorang sebesar 1,21\% dan untuk variabel pengalaman berpengaruh sebesar $81,00 \%$.

Pada gambar 6 akan ditampilkan hasil model SEM berdasarkan kualitas internet yang didapatkan (baik).

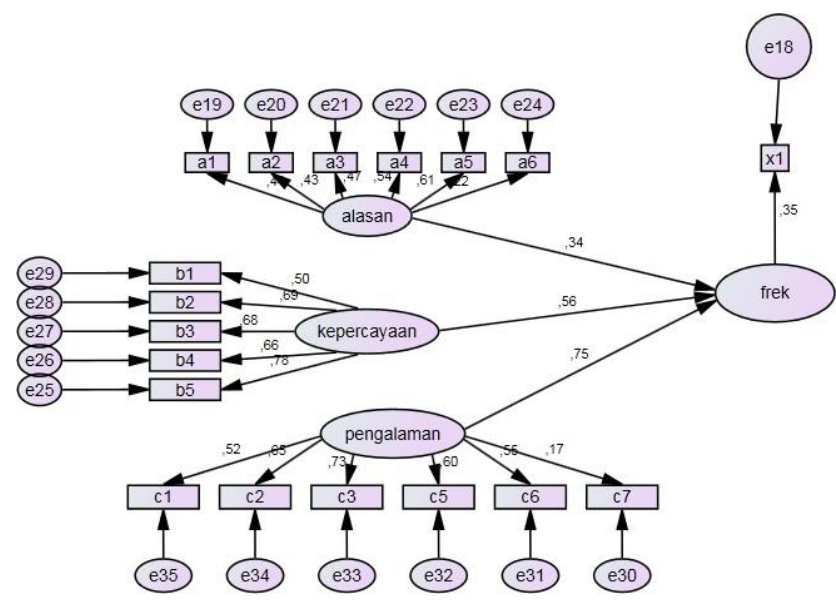

Gambar 6. Hasil model SEM berdasarkan kualitas internet yang didapat (baik)

Berdasarkan gambar 6 setelah angka koefisien jalur dikuadratkan, maka didapatkan kekuatan hubungan variabel alasan terhadap frekuensi belanja seseorang sebesar 11,56\%. Untuk variabel kepercayaan mempengaruhi frekuensi belanja online seseorang sebesar 31,36\% dan untuk variabel pengalaman berpengaruh sebesar 56,25\%.

Bila dilihat dari model-model diatas, bisa dilihat bahwa variabel pengalaman memiliki pengaruh terbesar terhadap frekuensi responden untuk melakukan belanja online $(54,76 \%)$, sedangkan pengaruh terkecil berasal dari variabel alasan (rata-rata 10,89\%). Berdasarkan nilai tersebut dapat disimpulkan bahwa alasan seseorang melakukan belanja online tidak berpengaruh besar terhadap frekuensi seseorang melakukan belanja online. Pada variabel tersebut terdapat indikator a1 dimana indikator tersebut merupakan indikator yang menyatakan seseorang melakukan belanja online dikarenakan kepraktisan, menghemat waktu, tenaga, tidak perlu keluar rumah.

Namun bila dilihat dari model berdasarkan gambar 6, alasan seseorang untuk melakukan belanja memiliki nilai pengaruh terbesar dibanding 3 model lainnya, maka bisa dikatakan bahwa dibanding 3 kondisi lainnya, kualitas internet cukup mempengaruhi alasan seseorang melakukan belanja online, walaupun tidak besar pengaruhnya.

Selain itu berdasarkan model diatas, kepercayaan juga mempengaruhi seseorang untuk melakukan belanja online. Menurut Armstrong dan Kohler (2003), kepercayaan merupakan satu dari empat faktor karakteristik psikologi yang mempengaruhi orang dalam membuat keputusan untuk membeli

\section{KESIMPULAN DAN DARAN}

\section{Kesimpulan}

Berdasarkan penelitian yang telah dilakukan dapat disimpulkan sebagai berikut:

1. Dari data yang didapatkan dari kuesioner, sebagian besar responden menyatakan pernah mengalami penglaman buruk selama melakukan belanja online (72\%), namun frekuensi mendapat pengalaman buruk terbilang jarang (rataan = 3,29 atau jarang). Berdasarkan data yang didapatkan dari metode SEM, dibandingkan 3 variabel lainnya, pengalaman merupakan variabel dengan pengaruh terbesar dan nilai signifikasi terkecil, sehingga dapat dikatakan pengalaman buruk saat belanja online merupakan variabel yang berpengaruh dalam frekuensi seseorang melakukan belanja online.

2. Faktor kepercayaan merupakan salah satu faktor yang berperan dalam frekuensi seseorang melakukan belanja online. Faktor-faktor yang secara signifikan mempengaruhi kepercayaan seseorang terhadap penelitian ini antara lain keamanan, kualitas, kecepatan transaksi, kecepatan pengiriman, dan kecocokan produk.

3. Berdasarkan 100 orang responden yang melakukan belanja online, 96 orang diantaranya menyatakan mereka masih melakukan belanja langsung. Hal ini menunjukkan bahwa layanan belanja online tidak mempengaruhi jumlah perjalanan belanja langsung secara signifikan.

4. Berdasarkan hasil kuisioner, pusat perbelanjaan (plaza, mall, dll) merupakan tujuan yang disukai oleh sebagian responden yang masih melakukan belanja langsung $(56,25 \%)$. 
5. Berdasarkan pendapat responden, 72 dari 100 orang berpendapat bahwa layanan belanja online dapat berpengaruh langsung terhadap berpengaruh terhadap perjalanan walaupun hal tersebut berlawanan dengan kebiasaan belanja yang mereka lakukan.

\section{Saran pemanfaatan penelitian}

Berdasarkan penelitian yang sudah dilakukan dapat direkomendasikan saran terhadap pemanfaatan penelitian, yakni:

1. Penelitian ini dapat dimanfaatkan sebagai pertimbangan dalam perencanaan sarana dan prasarana yang berhubungan dengan kegiatan belanja baik belanja langsung maupun belanja secara online.

2. Hasil penelitian ini dapat digunakan sebagai bahan referensi atau rujukan untuk penelitian selanjutnya yang mempunyai tema serupa dengan penelitian ini,

3. Hasil penelitian ini bisa digunakan untuk pihak-pihak pelaku jual beli via online atau pemilik toko-toko online, maupun pihak berwenang pada situs-situs belanja online untuk melakukan evaluasi dan peningkatan kinerja mereka.

4. Melihat belanja online mendapatkan respon yang baik dari masyarakat dikarenakan kelebihan-kelebihannya seperti praktis, banyak promosi dan lebih mudah membandingkan satu produk dengan yang lainnya, maka pemerintah dan pengusaha dapat meningkatkan keterlibatan masyarakat dalam belanja online guna mengurangi perjalanan yang tidak diperlukan.

\section{Saran terhadap penelitian selanjutnya}

Berdasarkan penelitian yang sudah dilakukan dapat direkomendasikan saran terhadap penelitian selanjutnya, yakni:

1. Variabel yang diuji agar dikaji ulang, sehingga bisa medapatkan korelasi yang lebih baik.

2. Model dari SEM sebaiknya dirancang sedemikian rupa dan sudah dirancang bersamaan dengan perencanaan kuisioner untuk mendapatkan model yang lebih baik.

3. Dilakukan penyebaran kuisioner secara langsung (offline) juga dikarenakan terdapat responden yang kurang memahami pertanyaan yang ada pada kuisioner secara online sehingga responden memberi respon yang kurang baik.

4. Ditambahnya jumlah responden khususnya untuk penggunaan metode SEM dikarenakan pada metode SEM, jumlah data yang disarankan dikisaran 100 sampai 200 data.

5. Perlu dibahas lebih lanjut mengenai hubungan antara jumlah kepemilikan kendaraan dengan frekuensi belanja seseorang.

6. Pada sektor kepercayaan dan pengalaman dibuat lebih spesifik mengenai kepercayaan dan pengalaman terhadap marketplace, vendor (lapak atai toko pada marketplace) dan terhadap kurir pengirim.

\section{DAFTAR PUSTAKA}

Grewal, et al. "Retail Branding and Costumer Loyalty: An Overview.” Journal of Retailing (2004).

Hendra, Y. N. R., E. Wirza dan Irawan M. Z. "Pengaruh Belanja Online Terhadap Perilaku Belanja.” Jurnal Transportasi 15 (1) (2015): 31-40.

Prihandini, T.I. dan S. Sunaryo. "Structural Equation Modelling (SEM) dengan Model Strukturan Regresi Spasial." Prosiding Seminar Nasional Statistika. Semarang: Universitas Diponegoro, 2011.

Sutoyo, A. Pemahaman Individu, Observasi, Checklist Interview, Kuisioner dan Sosiometri. Yogyakarta: Pustaka Belajar, 2009.

Tjakranegara, S. Hukum Pengangkutan Barang dan Penumpang. Jakarta: Rineka Cipta, 1996.

Vaitkevicius, S. dan Mazeikiene E. "Economic Demand Formation Motives in Online-Shopping.” 2019. Diunduh dari https://www.researchgate.net/ publication/337974980. 